\title{
PENGARUH MODEL PEMBELAJARAN BERBASIS MASALAH TERHADAP KETERAMPILAN SOSIAL DAN KEMAMPUAN PEMECAHAN MASALAH SISWA PADA PEMBELAJARAN IPS DI SMP NEGERI 5 TABANAN
}

\author{
Ni Putu Oka Dian Andayani ${ }^{1}$, I Putu Sriartha, lyus Akhmad Haris ${ }^{2}$ \\ Program Studi Pendidikan IPS, Program Pascasarjana \\ Universitas Pendidikan Ganesha \\ Singaraja, Indonesia \\ e-mail: okadian79@gmail.com ${ }^{1}$
}

\begin{abstract}
Abstrak
Tujuan penelitian ini adalah untuk mengetahui perbedaan : (1) keterampilan sosial antara siswa yang mengikuti model pembelajaran berbasis masalah dengan siswa yang mengikuti pembelajaran konvensional pada pembelajaran IPS di SMP Negeri 5 Tabanan; (2) kemampuan pemecahan masalah antara siswa yang mengikuti model pembelajaran berbasis masalah dengan siswa yang mengikuti pembelajaran konvensional pada pembelajaran IPS di SMP Negeri 5 Tabanan; dan (3) keterampilan sosial dan kemampuan pemecahan masalah secara simultan antara siswa yang mengikuti model pembelajaran berbasis masalah dengan siswa yang mengikuti pembelajaran konvensional pada pembelajaran IPS di SMP Negeri 5 Tabanan. Rancangan penelitian menggunakan penelitian kuasi eksperimen. Populasi dalam penelitian ini berjumlah 3 kelas dan 69 orang siswa. Sampel penelitian adalah 2 kelas berjumlah 46 siswa, 1 kelas sebagai kelas eksperimen dan 1 kelas sebagai kelas kontrol dan dipilih secara acak setelah dilakukan uji kesetaraan kelas. Hasil penelitian menunjukkan bahwa: (1) ada perbedaan keterampilan sosial siswa antara yang mengikuti pembelajaran dengan model pembelajaran berbasis masalah dan konvensional pada siswa kelas IX SMP Negeri 5 Tabanan dengan $F_{\text {hitung }}=93,639(p=$ $0,000<0,05)$, (2) ada perbedaan kemampuan pemecahan masalah siswa antara yang mengikuti pembelajaran dengan model pembelajaran berbasis masalahdan konvensional pada siswa kelas IX SMP Negeri 5 Tabanan dengan $F_{\text {hitung }}=58,582(p=$ $0,000<0,05)$, dan (3) terdapat perbedaan keterampilan sosial dan kemampuan pemecahan masalah siswa antara yang mengikuti pembelajaran dengan model pembelajaran berbasis masalah dan konvensional pada siswa kelas IX SMP Negeri 5 Tabanan dengan F-Wilks' Lambda $=75,388(p=0,000<0,05)$.
\end{abstract}

Kata kunci: Pembelajaran Berbasis Masalah, Keterampilan Sosial, Kemampuan Pemecahan Masalah

Abstract
The purpose of this study is to determine the differences: (1) social skills between students who follow the problem-based learning model with students who follow the conventional learning on social studies in SMP Negeri 5 Tabanan; (2) problem solving abilities between students who follow the problem-based learning model with students who follow the conventional learning on social studies in SMP Negeri 5 Tabanan; and (3) social skills and problem solving abilities simultaneously between students who follow the problem-based learning model with students who follow the conventional learning on social studies in SMP Negeri 5 Tabanan. The study design used quasi 
experimental research. The population in this study amounted to 3 classes and 69 students. The samples were 2 classes consisting of 46 students, 1 class as the experimental class and 1 class as the control class and randomly selected after the class equality test. The result of the research shows that: (1) there is difference of social skill between students who follow the learning with problem-based and conventional learning model in grade IX students of SMP Negeri 5 Tabanan with Fhitung = 93,639 ( $p$ $=0,000<0,05)$, (2) the difference of problem solving ability of students between the follow the learning with the model of problem-based and conventional learning on the students of class IX SMP Negeri 5 Tabanan with Fhitung $=58,582(p=0,000<0,05)$, and (3) there is difference of social skill and problem solving ability of student between those who followed the learning with problem-based and conventional learning model in the students of class IX SMP Negeri 5 Tabanan with F-Wilks' Lambda $=75,388(p=$ $0,000<0.05)$.

Keywords: Problem Based Learning, Social Skills, Problem Solving Abilities

\section{PENDAHULUAN}

Fungsi mata pelajaran IPS adalah sebagai suatu bidang kajian untuk mempersiapkan siswa mampu merefleksikan pengalamannya sendiri dan pengalaman orang lain, mengungkapkan gagasan-gagasan dan perasaan serta memahami beragam makna, sementara kegunaannya adalah untuk membantu siswa mengenal dirinya, budayanya, budaya orang lain, mengemukakan gagasan dan perasaan, berpartisipasi dalam masyarakat, membuat keputusan yang bertanggung jawab pada tingkat pribadi, sosial, menemukan serta menggunakan kemampuan analitik dan imajinatif yang ada dalam dirinya. Dengan demikian, mata pelajaran IPS berperan untuk pengembangan intelektual, sosial dan emosional siswa serta sebagai kunci penentu menuju keberhasilan dalam mempelajari suatu bidang tertentu. Untuk mewujudkan peran, fungsi, dan kegunaan mata pelajaran tsb.

Dalam proses pembelajaran IPS faktor guru memainkan peranan yang sangat penting.karena guru merupakan fasilitator dalam menerapkan model pembelajaran yang sesuai dengan tujuan kurikulum dan potensi siswa.

Berdasarkan berbagai jurnal yang terpublikasi dan pengalaman peneliti sebagai guru tidak semua guru mampu melaksanakan proses pembelajaran secara efektif karena berbagai kendala.
Salah satunya adalah dari dalam guru itu sendiri seperti kemauan menyiapkan bahan yang lebih baik, kemauan guru itu sendiri untuk menerapkan metode-metode pembelajaran yang tepat. Selain itu guru juga kurang mampu untuk mengembangkan keterampilan mengajar yang dapat menarik perhatian siswa dan merangsang siswa untuk belajar. Pemilihan model dan metode pembelajaran yang tepat akan berpengaruh terhadap keberhasilan dan hasil belajar siswa.

Salah satu tugas dan tanggung jawab guru yang membutuhkan ilmu dan seni mengajar adalah menciptakan suasana pembelajaran yang interaktif agar siswadapat berinteraksi dengan lingkungan secara aktif dan inspiratif agar merangsang siswa belajar untuk memecahkan masalah social yang dihadapi dan dialami. Permasalahanpermasalahan dalam pembelajaran IPS di sekolah yang sampai saat ini belum terpecahkan salah satu penyebabnya adalah karena kelemahan guru sebagaimana dikemukakan di atas.

Di tataran empiris pembelajaran di kelas masih dijumpai beberapa guru mempergunakan metode pembelajaran yang kurang cocok dengan karakteristik mata pelajaran dan siswa sehingga menyebabkan aktivitas pembelajaran menjadi tidak menggairahkan dan tidak 
menyenangkan (Nurhadi, dkk.,2004).Pada pembelajaran nyata di sekolah, secara umum pembelajaran IPS terbatas bersumber pada buku paket untuk dibaca dan LKS untuk dikerjakan tanpa disertai visualisasi berupa gambar atau foto sehingga siswa memahami IPS hanya berupa ingatan.

Pembelajaran IPS yang tertanam dalam pikiran siswa hanya sebagai pembelajaran yang membosankan dan bersifat hapalan. Hal ini terjadi karena pembelajaran kurang menyentuh nilai sosial dan keterampilan sosial siswa. Proses pembelajaran belum mampu membangun kemampuan individu dalam berhubungan dengan orang lain, terlibat dalam proses demokratis dan bekerja produktif dalam kelompok sosial. Sebagian besar guru merasa sudah mengajar dengan baik tetapi siswa tidak belajar sehingga terjadi miskonsepsi antara pemahaman guru dalam mengajar dengan target dan misi dari pembelajaran IPS yaitu sebagai mata pelajaran yang mengacu pada pembekalan pengetahuan dan keterampilan kepada siswa sebagai bekal dalam menjalani kehidupan bermasyarakat (Somantri, 2001).

Pembelajaran yang dilakukan oleh guru belum mampu membelajarkan siswa bagaimana bekerjasama, memecahkan masalah, dan menyikapi masalah sosial yang ada di lingkungan sekitar. Pengetahuan yang dimiliki siswa menjadi sangat terbatas karena pola pembelajarannya hanya mengandalkan materi pada LKS atau buku ajar. Padahal esensi dari IPS tidak terletak pada materi yang kaku tetapi lebih mendorong siswa utuk belajar menemukan konsep dari masalah-masalah yang terjadi di lingkungan sekitarnya. Inilah yang menyebabkan kegagalan pembelajaran IPS di sekolah-sekolah di Indonesia (Gunawan, 2011).

Melalui hasil observasi awal di SMP Negeri 5 Tabanan diperoleh keterangan bahwa masih terdapat beberapa kendala dalam proses pembelajaran IPS yaitu siswa belum terbiasa mengajukan pertanyaan dan pendapat, walaupun guru sering memberikan kesempatan kepada siswa untuk bertanya dan mengajukan pendapat, dibuktikan dari siswa terlihat pasif dan hanya menerima apa yang disampaikan oleh guru. Guru cenderung hanya menjelaskan materi yang terdapat pada LKS atau buku ajar. Metode yang digunakan mengarah pada konsep transfer ilmu saja sedangkan siswa pasif selama pembelajaran berlangsung. Siswa jarang mengemukakan alasan terhadap jawaban yang diberikan. Pada kegiatan penutup guru masih mendominasi dalam memberikan kesimpulan mengenai materi.

Penerapan model pembelajaran IPS yang inovatif dan efektif merupakan salah satu aspek pembelajaran yang sangat penting untuk mewujudkan tujuan pembelajaran. Salah satu model pembelajaran yang dinilai inovatif adalah model pembelajaran berbasis masalah. Pembelajaran ini mampu membawa siswa menggunakan pengetahuan yang diperoleh di kelas untuk menyelesaikan masalah-masalah baru yang belum pernah dihadapi, serta memiliki tanggung jawab terhadap belajarnya seiring dengan peningkatan pengalaman dan pengetahuan mereka. Pembelajaran Berbasis Masalah adalah "suatu pendekatan pengajaran yang menggunakan masalah dunia nyata sebagai suatu konteks bagi siswa untuk belajar tentang cara kemampuan pemecahan masalah dan keterampilan pemecahan masalah, serta untuk memperoleh pengetahuan dan konsep yang esensial dari materi pelajaran" (Nurhadi, dkk.2004).

Dengan penerapan model

Pembelajaran Berbasis Masalah diharapkan siswa lebih memahami pembelajaran IPS tidak hanya sebatas teori tetapi siswa memiliki keterampilan sosial dan kemampuan pemecahan masalah dalam kehidupan masyarakat. Melalui model pembelajaran ini dapat menjadikan siswa lebih aktif dan kreatif mencari makna dan akar dari suatu permasalahan dan juga memungkinkan siswa untuk melakukan diskusi bersama 
dalam memecahkan berbagai persoalan yang ada.

Berdasarkan identifikasi permasalahan dan dengan memperhatikan masalah yang telah diuraikan, maka peneliti mengajukan beberapa permasalahan yang menyangkut pengaruh model pembelajaran berbasis masalah terhadap keterampilan sosial dan kemampuan pemecahan masalah.

\section{METODE}

Penelitian ini merupakan penelitian kuasi eksperimen. Penelitian kuasi eksperimen bertujuan untuk menguji pengaruh variabel-variabel bebas terhadap variabel terikat (Arikunto, 2005). Penelitian yang dilakukan adalah penelitian kuasi eksperimen karena tidak semua variabel dan kondisi eksperimen dapat diatur dan dikontrol secara ketat. Sebelum menetapkan rancangan penelitian, terlebih dahulu dilakukan pengujian kesetaraan kelas dengan menggunakan ANAVA satu jalur. Berdasarkan hasil pengujian kesetaraan kelas, maka dalam penelitian ini mengikuti rancangan eksperimen theposttest only control group design.Dalam rancangan ini subjek yang diambil dari populasi dikelompokkan menjadi dua yaitu kelompok eksperimen dan kelompok kontrol secara acak. Kelompok eksperimen dikenai perlakuan dengan model pembelajaran berbasis masalah dan kelompok kontrol dikenai perlakuan model konvensional dalam jangka waktu tertentu, kemudian kedua kelompok dikenai pengukuran yang sama.

Adapun yang menjadi prosedur dalam penelitian ini antara lain: (1) orientasi dan observasi terhadap rancangan dan pelaksanaan belajar mengajar di kelas, selain juga melakukan diskusi intensif dengan guru yang mengajar di kelas tersebut, (2) menyusun dan merancang perangkat pembelajaran yang terdiri atas rencana pelaksanaan pembelajaran (RPP), lembar kerja siswa (LKS), serta menyiapkan lembar observasi serta menyusun tes untuk mengukur kemampuan pemecahan masalah siswa, (3) menganalisis tes akhir semester ganjil untuk menguji kesetaraan kelompok sebelum diberikan perlakuan, (4) melaksanakan pembelajaran berbasis masalah pada kelompok eksperimen dan kelompok kontrol mendapat perlakuan pembelajaran konvensional, mengadakan post test (tes akhir) untuk mengidentifikasi kemampuan pemecahan masalah yang telah dicapai siswa, dan (6) menganalisis data keterampilan sosialdan kemampuan pemecahan masalah siswa.

Dalam tahap pelaksanaan ini tidak ada perbedaan materi yang diberikan baik untuk kelompok eksperimen maupun kelompok kontrol, yang membedakan diantara keduanya adalah model pembelajaran yang digunakan. Di bawah ini dapat dilihat sintaks dari kegiatan guru maupun siswa dalam proses pembelajaran baik menggunakan model berbasis masalah maupun model pembelajaran konvensional.

\section{HASIL DAN PEMBAHASAN}

Data yang telah terkumpul dalam penelitian ini ditabulasikan sesuai dengan keperluan analisis data yang tercantum dalam rancangan penelitian yang bertujuan untuk memberikan gambaran umum mengenai penyebaran atau distribusi data. Sebagaimana telah dikemukakan bahwa penelitian ini adalah penelitian eksperimen dengan analisis ujianava satu jalur dan manova sehingga berdasarkan rancangan tersebut maka deskripsi data yang akan disajikan pada bagian ini terdiri atas empat kelompok, yaitu (1) keterampilan sosial siswa yang mengikuti pembelajaran dengan model pembelajaran berbasis masalah, (2) kemampuan pemecahan masalah siswa yang mengikuti pembelajaran dengan model pembelajaran berbasis masalah (3) keterampilan sosial siswa yang mengikuti pembelajaran dengan model pembelajaran konvensional, dan (4) kemampuan pemecahan masalah siswa 
yang mengikuti pembelajaran dengan model pembelajaran konvensional.

Masing-masing dari empat distribusi tersebut disajikan dengan cara meyajikan rata-rata sebagai ukuran pemusatan, standar deviasi sebagai ukuran penyebaran, tabel frekuensi, dan histogram. Rekapitulasi hasil perhitungan skor (1) keterampilan sosial siswa yang mengikuti pembelajaran dengan model pembelajaran berbasis masalah,

(2) kemampuan pemecahan masalah

Tabel 1 Rekapitulasi Hasil Perhitungan Skor Keterampilan Sosial dan Kemampuan

Pemecahan Masalah Siswa yang Mengikuti Pembelajaran dengan Model Pembelajaran Berbasis Masalah dan Konvensional bawah ini

\begin{tabular}{|c|c|c|c|c|}
\hline \multirow{2}{*}{ Statistik } & \multicolumn{2}{|l|}{$A_{1}$} & \multicolumn{2}{|l|}{$\mathrm{A}_{2}$} \\
\hline & $Y_{1}$ & $Y_{2}$ & $Y_{1}$ & $\mathrm{Y}_{2}$ \\
\hline Mean & 104.826 & 81.739 & 94.044 & 73.391 \\
\hline Median & 106.000 & 82.000 & 95.00 & 74.00 \\
\hline Modus & 106.00 & 82.00 & 96.00 & $76.00^{a}$ \\
\hline Std. Deviasi & 3.393 & 3.208 & 4.128 & 4.131 \\
\hline Varians & 11.514 & 10.292 & 17.043 & 17.067 \\
\hline Range & 12.00 & 10.00 & 13.00 & 13.00 \\
\hline Skor minimum & 98.00 & 77.00 & 87.00 & 67.00 \\
\hline Skor maksimum & 110.00 & 87.00 & 100.00 & 80.00 \\
\hline Jumlah & 2411.00 & 1880.00 & 2163.00 & 1688.00 \\
\hline
\end{tabular}

Keterangan:

$\mathrm{A}_{1}=$ Model pembelajaran berbasis masalah

$A_{2}=$ Model pembelajaran konvensional

$\mathrm{Y}_{1}=$ Keterampilan sosial

$\mathrm{Y}_{2}=$ Kemampuan pemecahan masalah

Berdasarkan hasil pengujian hipotesis yang telah diuraikan di atas terlihat bahwa ketiga hipotesis yang diajukan pada penelitian ini telah berhasil menolak hipotesis nol dan dapat disimpulkan bahwa terdapat perbedaan antara keterampilan sosial dan kemampuan pemecahan masalah antara siswa yang belajar dengan model PBL dengan siswa yang belajar dengan model pembelajaran konvensional.

Hasil perhitungan menunjukkan bahwa perbedaan keterampilan sosial siswa yang mengikuti pembelajaran dengan model pembelajaran berbasis masalahpada siswa kelas IX SMP Negeri 5 Tabanan dengan skor rata-rata 104,826, sedangkan keterampilan sosial siswa siswa yang mengikuti pembelajaran dengan model pembelajaran berbasis masalah, (3) keterampilan sosial siswa yang mengikuti pembelajaran dengan model pembelajaran konvensional, dan (4) kemampuan pemecahan masalah siswa yang mengikuti pembelajaran dengan model pembelajaran konvensional dapat diikhtisarkan seperti Tabel 1 di

yang mengikuti pembelajaran dengan pembelajaran konvensional pada siswa kelas IX SMP Negeri 5 Tabanan dengan skor rata-rata 94,044. Ternyata skor ratarata keterampilan sosial siswa yang mengikuti pembelajaran dengan model pembelajaran berbasis masalahlebih tinggi daripada sikap siswa yang mengikuti pembelajaran dengan pembelajaran konvensional pada siswa kelas IX SMP Negeri 5 Tabanan. Dengan demikian, dapat disimpulkan keterampilan sosial siswa yang mengikuti pembelajaran dengan model pembelajaran berbasis masalah lebih tinggi daripada sikap siswa yang mengikuti pembelajaran dengan pembelajaran konvensional pada siswa kelas IX SMP Negeri 5 Tabanan.

Model pembelajaran berbasis masalah adalah suatu model pembelajaran yang menggunakan masalah dunia nyata sebagai suatu 
konteks bagi siswa untuk belajar berpikir kritis dan keterampilan pemecahan masalah, serta untuk memperoleh pengetahuan yang esensial dari sebuah mata pelajaran. PBL memiliki gagasan bahwa pembelajaran dapat dicapai jika kegiatan pendidikan dipusatkan pada tugas-tugas atau permasalahan yang autentik, relevan dan dipresentasikan dalam suatu kontek. Menurut Bono dalam Amir (2015) pendidikan bukanlah tujuan kita. Pendidikan harus mempersiapkan pembelajar untuk hidup. Dengan demikian maka dengan PBL memiliki peluang untuk membangaun kecakapan hidup (life skills) pemelajar; pemelajar terbiasa mengatur dirinya sendiri (self directed), berpikir metakognitif (refleksi dengan pikiran dan tindakannya), berkomunikasi dan berbagai kecakapan terkait. Smith (2005) yang khusus meneliti berbagai dimensi manfaat diatas menemukan bahwa pemelajar akan meningkat kecakapan pemecahan masalah, lebih mudah mengingat, meningkat pemahamanya, meningkat pengetahuannya yang relevan dengan dunia praktik, mendorong mereka penuh pemikiran, membangun kemampuan kepemimpinan dan kerja sama, kecakapan belajar, dan memotivasi pemelajar.

Dengan demikian dapat disimpulkan bahwa terdapat perbedaan keterampilan sosial siswa antara yang mengikuti pembelajaran dengan model pembelajaran berbasis masalahdan konvensional pada siswa kelas IX SMP Negeri 5 Tabanan.

Hasil perhitungan menunjukkan bahwa kemampuan pemecahan masalah siswa yang mengikuti pembelajaran dengan model pembelajaran berbasis masalahpada siswa kelas IX SMP Negeri 5 Tabanan dengan skor rata-rata 81,739, sedangkan kemampuan pemecahan masalah siswa yang mengikuti pembelajaran dengan pembelajaran konvensional pada siswa kelas IX SMP Negeri 5 Tabanan dengan skor rata-rata 73,391. Ternyata skor rata-rata kemampuan pemecahan masalah siswa yang mengikuti pembelajaran dengan model pembelajaran berbasis masalahlebih tinggi daripada sikap siswa yang mengikuti pembelajaran dengan pembelajaran konvensional pada siswa kelas IX SMP Negeri 5 Tabanan. Dengan demikian, dapat disimpulkan kemampuan pemecahan masalah siswa yang mengikuti pembelajaran dengan model pembelajaran berbasis masalah lebih tinggi daripada sikap siswa yang mengikuti pembelajaran dengan pembelajaran konvensional pada siswa kelas IX SMP Negeri 5 Tabanan.

Keberhasilan penelitian ini sesuai dengan apa yang dinyatakan oleh Tan (dalam Rusman, 2013: 229) Problem Based Learning merupakan inovasi dalam pembelajaran karena dalam PBL kemampuan berfikir siswa betul-betul dioptimalkan melalui proses kerja kelompok atau tim yang sistematis, sehingga siswa dapat memberdayakan, mengasah, menguji dan mengembangkan kemampuan berpikirnya secara berkesinambungan. Sejalan juga dengan pendapat Boud dan Feleti (dalam Rusman, 2013: 230) mengemukakan bahwa Problem Based Learning adalah inovasi yang paling signifikan dalam pendidikan. Sejalan dengan apa yang dikemukakan Boud dan Feletti, Margetson (dalam Rusman, 2013: 230) mengemukakan bahwa kurikulum Problem Based Learning membantu untuk meningkatkan perkembangan keterampilan belajar sepanjang hayat dalam pola pikir yang terbuka, reflektif kritis, dan belajar aktif dan akhirnya bermuara pada kemampuan pemcahan masalah siswa. 
Belajar berdasarkan masalah dikembangkan untuk membantu siswa mengembangkan kemampuan berpikir, memecahkan masalah dan keterampilan intelektual. Di samping itu, pembelajaran berbasis masalah memberikan kesempatan belajar berbagai peran orang dewasa melalui pelibatan mereka dalam pengalaman nyata atau simulasi serta menjadi pebelajar yang otonom dan mandiri (Ibrahim, 2000). Pembelajaran merbasis masalah dapat mengembangkan kemampuan berpikir tingkat tinggi. Hal ini didukung oleh Hastings (dalam Arnyana, 2004) yang mengemukakan bahwa belajar berdasarkan masalah dapat mengembangkan keterampilan kemampuan pemecahan masalah dan analitis serta menghadapkan siswa pada latihan untuk memecahkan masalah

Uraian di atas mengisyaratkan bahwa secara teori dan empiris ternyata pembelajaran berbasis masalah berpengaruh terhadap keterampilan social dan kemampuan pemecahan masalah secara parsial dan simultan. Dengan demikian dapat dinyatakan bahwa ada perbedaan keterampilan sosial dan kemampuan pemecahan masalah siswa secara simultan antara yang mengikuti pembelajaran dengan model pembelajaran berbasis masalah dan konvensional pada siswa kelas IX SMP Negeri 5 Tabanan.

Temuan penelitian ini adalah bahwa keterampilan sosial dan kemampuan pemeahan masalah siswa diajar dengan model pembelajaran problem based learning lebih tinggi dibandingkan dengan siswa yang diajar dengan model pembelajaran pembelajaran konvensional secara terpisah maupun simultan. Dalam model pembelajaran PBL, setiap siswa didorong untuk dapat mengkonstruk pengetahuannya sendiri dengan cara meleburkan pengetahuan dan pengalaman yang ada dengan pengetahuan yang baru. Dalam proses pemecahan masalah yang disajikan, siswa akan mengidentifikasi dan menggali berbagai informasi yang dibutuhkan untuk menyelesaikan masalah tersebut. Dengan karakteristik yang menekankan setiap siswa untuk aktif dalam pembelajarannya, maka materi dalam PBL disusun dengan struktur yang dapat mendukung proses kemandirian belajar para siswa sehingga mereka dapat mengembangkan pemikiran kritis, pembelajaran mandiri, keterampilan dan sikap terhadap proses kelompok. Sedangkan pada model pembelajaran konvensional lebih menekankan proes penyampaian informasi oleh guru kepala siswa.

\section{SIMPULAN}

Berdasarkan analisis dan pembahasan seperti yang telah dipaparkan pada bagian sebelumnya, maka dapat disimpulkan beberapa hal sebagai berikut.ada perbedaan keterampilan sosial siswa antara yang mengikuti pembelajaran dengan model pembelajaran berbasis masalah dan konvensional pada siswa kelas IX SMP Negeri 5 Tabanan dengan $F_{\text {hitung }}=93,639$ $(\mathrm{p}=0,000<0,05)$, ada perbedaan kemampuan pemecahan masalah siswa antara yang mengikuti pembelajaran dengan model pembelajaran berbasis masalahdan konvensional pada siswa kelas IX SMP Negeri 5 Tabanan dengan $F_{\text {hitung }}=58,582(p=0,000<0,05)$, ada perbedaan keterampilan sosial dan kemampuan pemecahan masalah siswa antara yang mengikuti pembelajaran dengan model pembelajaran berbasis masalahdan konvensional pada siswa kelas IX SMP Negeri 5 Tabanan dengan F-Wilks' Lambda=7,388 ( $p=0,000<$ $0,05)$.

Hasil penelitian menunjukkan bahwa model pembelajaran berbasis masalah berpengaruh terhadap keterampilan sosial dan kemampuan pemecahan masalah siswa secara terpisah maupun simultan. Berdasarkan kesimpulan dan implikasi penelitian yang telah dipaparkan di atas, maka kepada guru disarankan

Dian Andayani | $\mathbf{4 0}$ dari $\mathbf{5 0}$ 
menggunakan model pembelajaran berbasis masalah sebagai upaya untuk meningkatkan keterampilan sosial dan kemampuan pemecahan masalah siswa. Untuk itu disarankan sebagai berikut.para guru IPS Sekolah Menengah Pertama (SMP) disarankan menggunakan model pembelajaran Problem Based Learning (PBL) sebagai model pembelajaran alternatif dalam pembelajaran IPS di sekolah Menengah Pertama, karena model pembelajaran berbasis masalah merupakan salah satu model pembelajaran yang dapat membuat siswa menjadi aktif, guru hendaknya selalu melakukan inovasi dalam proses pembelajaran agar dapat merencanakan dan melaksanakan pembelajaran berbasis masalah sesuai tuntutan KTSP serta lebih mengintensifkan penggunaan media pembelajaran, bagi sekolah, sekolah hendaknya menyediakan sarana dan prasarana yang menunjang pembelajaran berbasis masalah. Kepala sekolah hendaknya menggiatkan penggunaan media pembelajaran oleh guru sesuai dengan KTSP, dan bagi Dinas Pendidikan disarankan untuk menyelenggarakan peningkatan kompetensi guru sekolah dasar, khususnya mengenai penerapan pembelajaran berbasis masalah sesuai dengan KTSP.

\section{DAFTAR PUSTAKA}

Barrows. 1996. Problem Based learning in Medicine and Beyond. Jakarta: Prenada Media Group

Cartledge, G. \& Millburn, J. F. 1995. Teaching Social Skills to Children \&Youth. Innovative Aproach, 3rd ed. Massachussets: Allyn \& Bacon.

Edgen, Paul. 2012. Strategi dan Model Pembelajaran Mengajarkan Konten dan Keterampilan Berfikir. Jakarta : PT. Indeks.

Gimpel, G.A. \& Merrell, K.W. 1998. Social Skill of Children and Adolescents: Conceptualization, Assessment, Treatment. New Jersey: Lawrence Erlbaum.

Gunawan, Rudy. 2013. Pendidikan IPS Filosofi, Konsep, dan Aplikasi (Edisi Revisi). Jakarta: Alfabeta

Ibrahim, Muslimin dan Mohammad Nur. 2000. Pengajaran Berdasarkan Masalah. Surabaya: Unesa University Press.

Jarolimek, J. 1993. Social Studies in lementary Education. New York: Mc.MillanPublishing.

Prayitno.1980. Dinamika Kelompok \& Kerja Kelompok.Jakarta : P3G Depdikbud

Rusman.

2010. Model-Model Pembelajaran. Jakarta: PT Raja Grafindo Persada

Trianto. 2007. Model-model Pembelajaran Inovatif Berorientasi Konstruktivistik. Jakarta : Prestasi Pustaka Publisher.

Wardoyo, Sigit Mangun. 2013. Pembelajaran Berbasis Riset. Jakarta: Akademia Permata 